\title{
LATVIA'S PROGRESS TOWARDS A RETIREMENT SOCIETY: AGEING TRENDS IN LATVIAN MUNICIPALITIES
}

\section{Latvijas virzība uz pensionāru sabiedrību: novecošanās tendences Latvijas novados}

\author{
Gunta Grube, Juris Paiders \\ University of Latvia, Faculty of Geography and Earth Sciences \\ e-mail: jpaiders@inbox.lv
}

\begin{abstract}
This paper analyses the ageing of the population, which may become one of the most important social changes of the 21st century in the European Union. This work uses statistics from the Central Statistical Bureau (CSB) of Latvia, as well as statistics prepared by the State Social Insurance Agency of Latvia (SSIA). The results suggest that the economic development and the stabilisation of employment in Riga and Riga region in the second decade of the 21 st century was ensured not by generational change or migration, but by the inclusion of members of the population who had previously been economically inactive into the labour market. This may lead to the conclusion that around 2030, the ageing of the population will become one of the most serious problems in Pieriga.
\end{abstract}

Keywords: ageing, population structure change, pension recipients, migration, employment

DOI: $10.22364 / \mathrm{fg} .18 .5$

\section{Introduction}

One of the important directions of modern scientific research in geography is related to structural changes in the population, both analysing how this happens at different spatial levels (Govindaraju 2014) and by identifying possible solutions (Backus et al. 2014). Since migration affects the age structure in migration-affected areas and causes changes in the working-age population, at a global level it is the impact of migration on changes in population structure that is mainly studied (McAuliffe et al. 2017; Stillwell et al. 2016; Arango 2017; Danchev 2018). Similar studies are being conducted at the European level (Rechel et al. 2013; O'Reilly 2015; Brekke 2015; Nica 2015; Wilson et al. 2013; De Vries et al. 2019). Many studies have also been carried out in Latvia, both on migration processes taking place in the territory of Latvia (Apsīte-Beriņa et al. 2019; Burgmanis et al. 2014; Göler et al. 2014), as well as on the manifestations of emigration and immigration (McCollum et al. 2017; Göler et al. 2016; Apsite-Berina 2018).

The ageing of the population may become one of the most important social changes of the 21 st century in the European Union. The proportion of people over the age of 60 is currently around $15 \%$ in the EU, but this figure is expected to reach $30 \%$ by 2050 (Sanderson et al. 2017; Giacalone et al. 2016). Changes in the structure of the population can be predicted to affect labour and financial markets (Maestas et al. 2016), family structures and intergenerational ties (Giacalone et al. 2016), and to have 
an impact on future economic indicators (Alho et al. 2006; Zavras et al. 2013; Backus et al. 2014; Juselius et al. 2015; Maestas et al. 2016; Colby et al. 2014).

Ageing trends are mainly studied at the national level (Bloom et al. 2016;), with predictions about ageing trends in the 21st century being expressed (Alho et al. 2006; Sanderson et al. 2017).

The aim of this work was to describe ageing trends among the population of Latvia by comparing the areas surrounding the capital with other regions of Latvia.

\section{Data and methods}

This work uses statistics from the Central Statistical Bureau of Latvia (CSB), as well as statistics prepared by the State Social Insurance Agency of Latvia (SSIA) on the number of pension recipients administered and the average (gross) pension payments granted by administrative territory in December of each year (from 2011 to 2018) and in September (for 2019); and on the number of persons socially insured by the SSIA by administrative territory in December of each year (from 2011 to 2018) and in September 2019.

The methodology used by Eurostat (Population Projections 2015) and tested in other scientific publications (Paiders 2019) was used in preparing the forecasts. It was assumed that Latvia's natural growth and relative domestic migration balance in the future would be in line with the trends observed from 2016 to 2019, but that the relative international migration balance would be zero from 2020 onwards.

It was also assumed that mortality in each age group would correspond to the average mortality by age group in the Riga region in 2018 .

The projected population was calculated according to the following formula:

$$
I_{x+1}=I_{x}+I_{x}\left(D_{m}+R_{m}\right),
$$

where

$I_{x}$ - population in the given year,

$I_{x+1}$ - population in the following year,

$D_{m}$ - average relative natural increase between 2016 and 2019,

$R_{m}$ - average relative balance of domestic migration between 2016 and 2019.

The calculation for the forecast was started using the actual population in 2019.

The projected population in the age group is calculated according to the following formula:

$I_{x+1}=I_{x}-I_{x} * M_{m}$

where

$I_{x}$ - population in the given year in the relevant age group,

$I_{x+1}$ - population in the following year in the relevant age group,

$M_{m}$ - average relative mortality (mortality rate per 1,000 people multiplied by $1,000)$ in the relevant age group. 
The projected number of pensioners was calculated according to the linear regression formula:

$P=A+B x$, where

$\mathrm{P}$ - the projected number of pensioners;

$\mathrm{B}=\frac{\sum(x-\bar{y})(y-\bar{y})}{\sum(x-\bar{x})^{2}}$ and $\mathrm{A}=y-\mathrm{B} x$, where

$\mathrm{x}$ - observation sequence number,

$\mathrm{y}-$ population in the relevant year.

The calculations of the correlation coefficient of the total for pensions were carried out according to the following formula:

$\mathrm{C}=\frac{\sum(x-)(y-\bar{y})}{\sqrt{\sum(x-\bar{x})^{2} \sum(y-\bar{y})^{2}}}$, where

$\bar{x}$ and $\bar{y}$ - average sample rates.

The significance between pension payments in the regions of Latvia was calculated according to the following formula:

$$
\begin{aligned}
& t=\frac{\bar{x}_{1}-\bar{x}_{2}}{\sqrt{s^{2}}\left(\frac{1}{n_{1}}+\frac{1}{n_{2}}\right)} \\
& s^{2}=\frac{\sum_{i=1}^{n 1}\left(x_{i}-\bar{x}_{1}\right)^{2}+\sum_{j=1}^{n 2}\left(x_{j}-\bar{x}_{2}\right)^{2}}{n_{1}+n_{2}-2}, \text { where }
\end{aligned}
$$

$\bar{x}_{1}$ and $\bar{x}_{2}$ - sample means;

$\mathrm{s}^{2}-$ pooled sample variance;

$\mathrm{n}_{1}$ and $\mathrm{n}_{2}-$ sample sizes;

$\mathrm{t}-$ Student $\mathrm{t}$ quantile with $\mathrm{n}_{1}+\mathrm{n}_{2}-2$ degrees of freedom.

The data processing and calculations required for the work were performed using MS Excel 2016 software, while the computer programme ArcGIS was used to visualise the results and prepare images.

\section{Results}

\section{Employment and ageing trends in Riga and Pieriga}

According to the CSB data, the total number of people in the age group between 15 and 64 is continuing to decrease in Riga. At the same time, the number of economically active (self-employed and employed people) in the age group between 15 and 64 has stabilised since 2013. In turn, in 2018, the number of unemployed in the age group between 15 and 64 in Riga reached the second-lowest level $(21,600$ inhabitants) since 1996. The number of unemployed in the age group between 15 and 64 in Riga was lower only in 2007, when the total was 20,900 inhabitants. According to the CSB data, the stabilisation of the economically active and employed population in the age group between 15 and 64 took place as the number of economically inactive people (especially the unemployed) in this age group decreased. As a result, in Riga, the level of economic activity in the age group between 15 and 64 years in 2018 reached a historic peak of $81.2 \%$. The employment rate in Riga in the age group 
between 15 and 64 also reached its historical peak in $2018-75.8 \%$. In turn, the unemployment rate in Riga in the age group between 15 and 64 years in 2018 was the lowest since 2009 - just $6.6 \%$. The unemployment rate in Riga in the age group between 15 and 64 years was lower only in 2007 and 2008.

In 2018, Riga was approaching its historic peak employment level. Economic development and the stabilisation of employment in Riga in the second decade of the 21 st century was ensured not by generational change or migration, but by the inclusion in the labour market of members of the population who had previously been economically inactive.

\section{Migration and employment trends in the Pieriga region}

Starting from the mid-1990s, a significant number of Rigans moved from Riga to Pieriga. An important motive for moving out of Riga at that time was the rather poorly developed service system, which is often referred to as the benefits of city living (available communication, shopping and catering services; available entertainment and leisure opportunities, etc.). Assessing conditions in the 21 st century, it must be stated that the availability of housing in Riga has significantly improved. This was facilitated by the reduction of the population of Riga, as well as the construction of new residential buildings and the modernisation of old buildings. In addition to this, Riga has developed a system of well-accessible services related to the aforementioned benefits of city living that is at the level of Western European metropolises. In addition, the generation that has grown up in housing around Riga has never felt a lack of living space as their parents did but do strongly perceive the inconveniences that arise from living outside the city, especially the separation from city services.

According to the CSB data, in the Pieriga region, the total number of people in the age group between 15 and 64 years increased from the mid-1990s, reaching a historical peak of 251,400 inhabitants in 2010. In the Pieriga region from 2010 onwards, the total population in the age group between 15 and 64 years tended to decrease. From 2006 onwards, the number of economically active people in the Pieriga region in the age group between 15 and 64 stabilised at a level slightly above 180,000 , while the number of employed people stabilised at the level of about 170,000 . In 2018, the number of employed people in the Pieriga region in the age group between 15 and 64 years reached the second-highest level (174,300 inhabitants) since 1996. The higher number of employed people in the Pieriga region in the age group between 15 and 64 years was recorded in 2008 (176,200 inhabitants). In turn, in 2018 , the proportion of unemployed people in the age group between 15 and 64 years in the Pieriga region reached a historical low of $8.8 \%$.

The stabilisation number of the economically active and employed people in the Pieriga region in the age group between 15 and 64 years took place as the number of economically inactive people in this age group decreased. As a result, the level of economic activity in the Pieriga region in the age group between 15 and 64 years 
reached a historic peak of $79.5 \%$ in 2018 . The employment rate in the Pieriga region in the age group between 15 and 64 years also reached a historic peak of $75.7 \%$ in 2018, while the unemployment rate in the Pieriga region in the age group between 15 and 64 years reached a historical low of $4.8 \%$ in 2018.

Similar to Riga, in 2018 the Pieriga region was approaching its historic peak employment level. Economic development and employment stabilisation in the Pieriga region in the second decade of 21 st century was ensured not by generational change or migration, but by the inclusion in the labour market of members of the population who had previously been economically inactive.

\section{Ageing trends in Pieriga and regions of Latvia}

Assuming that 2016-2019 trends in natural growth and internal migration will continue, but that from 2020 onwards the external migration balance is zero, then it can be predicted that the population of Latvia will decrease from 1.92 million at the beginning of 2019 to 1.83 million in 2030 and to 1.70 million in 2050. This scenario is close to Eurostat 2030's recalculated forecasts regarding changes to the population of Latvia, which do not include international migration. If the conditions included in the model are met, then in 2030, there will be 492,000 people in the age group over 65 living in Latvia, of whom 144,000 will be living in Riga and 106,000 in Pieriga. Compared to the beginning of 2019, the total number of representatives of the oldest population group will increase by $0.6 \%$ in Latvia by 2030 , and by $11.7 \%$ in Riga, while in Pieriga by as much as 58.0\%". Such significant differences in ageing trends can be explained by the fact that in 2030 the the members of the population of the population who moved to Pieriga at the beginning of the 21 st century when they were of working age will have will have become pensioner. Therefore, it can be predicted that around 2030 its aging population will become one of the most serious problems in Pieriga. The number of people in the age group over 65 could increase by more than $60 \%$ in Baloži, Stopiṇi, Garkalne, Babīte, Ādaži, Saulkrasti, Carnikava and Mārupe municipalities.

Table 1. The proportion of the population over $65(\%)$ against the total population in Latvia and the regions of Latvia on 1st January 2019, and the forecast for 2030 (authors' calculations based on data from CSB)

\begin{tabular}{|c|c|c|}
\hline Age groups & $\begin{array}{c}\text { Year 2019 } \\
\mathbf{> 6 5}\end{array}$ & $\begin{array}{c}\text { Year 2030 } \\
\mathbf{7 6 5}\end{array}$ \\
\hline LATVIA & 20.3 & 21.3 \\
\hline Riga & 20.4 & 23.1 \\
\hline Pieriga region & 18.1 & 26.3 \\
\hline Vidzeme region & 21.3 & 17.4 \\
\hline Kurzeme region & 21.1 & 18.7 \\
\hline Zemgale region & 19.6 & 17.7 \\
\hline Latgale region & 21.9 & 19.4 \\
\hline
\end{tabular}


In turn, the opposite trend can be predicted in the rest of Latvia (Table 1). According to the forecast, in 2030 the ratio of the population over 65 to the total population will decrease in all regions of Latvia except Riga and Pieriga. In Riga the population over 65 will increase slightly, but in Pieriga it will increase significantly.

\section{Ageing trends in the regions of Latvia}

According to the CSB data, $20 \%$ of the population of Latvian were over 65 years of age. At the beginning of 2019, there were 1,187 places in Latvia with a population of more than 50. In 55 of these the proportion of the population aged 65 and over exceeds $30 \%$. The areas with the largest proportion of the population aged 65 and over are 15 densely populated areas which have care facilities for the elderly: in Ziedugrava (92\%), Liepkalne school (84\%), the Siltais social care centre (82\%), Rokaiži (82\%), Gatarta nursing home (73\%), Mežmalieši (66\%), Rauda (64\%), Salenieki in Aglona parish (63\%), Valtaiķi nursing home (63\%), Urga (62\%), Landze (61\%), Lauciene nursing home (60\%), Western Lutrini (60\%), Îslīce nursing home $(60 \%)$ and Celmene (59\%) (CSP publicē, 2020). Since the number of elderly people is proportionally higher in municipalities and parishes where care facilities for the elderly are located than in the neighbouring territories, this limits the possibility for mathematical-statistical methods to be used in the research.

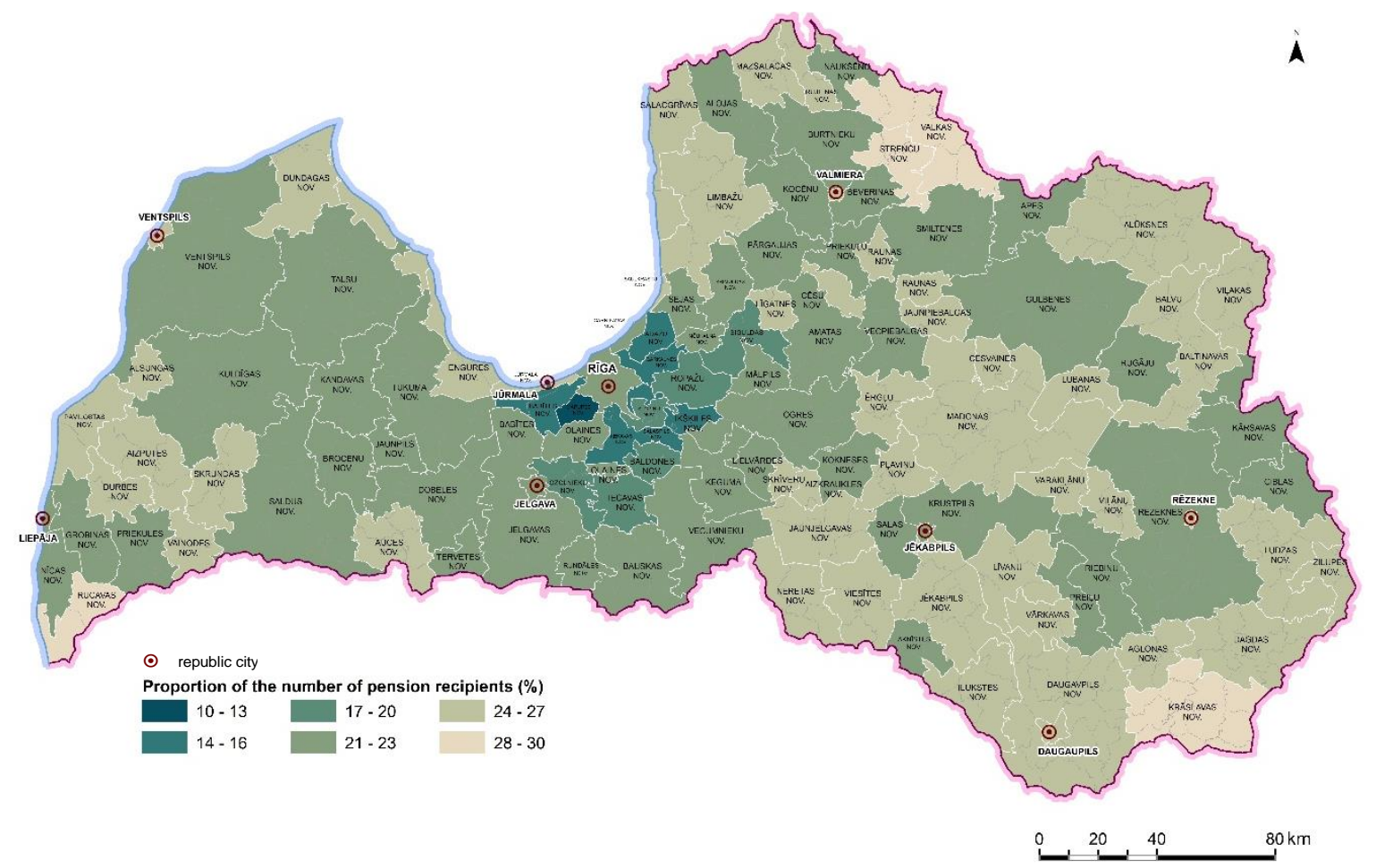

Figure 1. The proportion of the number of pension recipients (\%) in September 2019 against the total proportion of working-age population (15-74) in the regions of Latvia (authors' calculations based on SSIA statistical data and Envirotech spatial data)

According to data on the location of pension recipients in September 2019 (Figure 1), the ratio of the number of pensioners to the total working-age population in 
Pieriga differs significantly from the trends in the rest of Latvia. Forecasts show that the total working-age population of the municipalities in Pieriga in 2030 could decrease to $56 \%$ of the total working-age population.

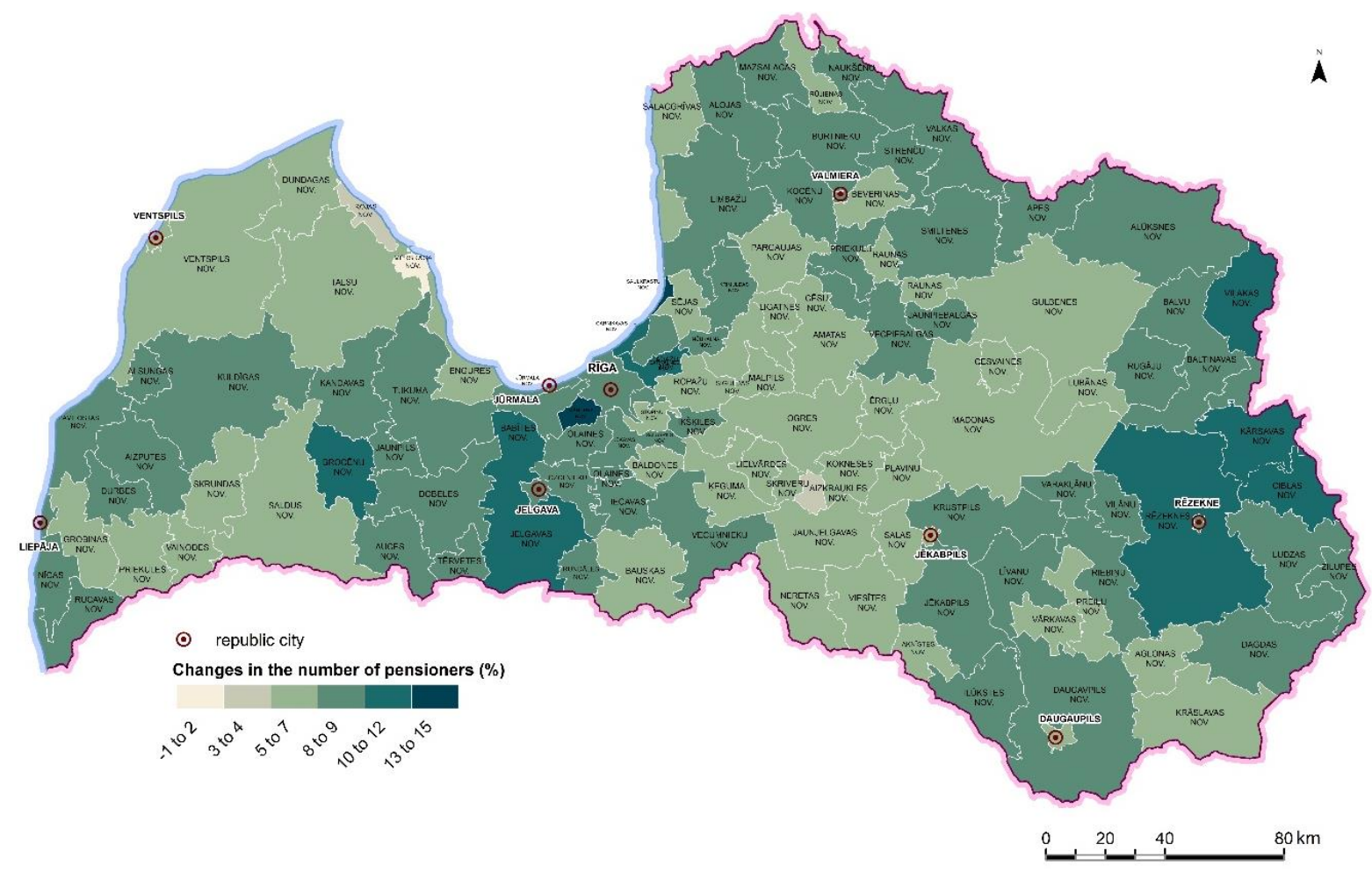

Figure 2. Changes in the number of pensioners (\%) between 2011 and 2019 (authors' calculations based on SSIA statistical data and Envirotech spatial data)

On the other hand, there are both similar and varying tendencies in the share of pensioners" and then add where this applies - e.g. "in different municipalities/regions Carrying out a linear forecast from this indicator, it can be concluded that in 2030, there will be 400,000 pensioners (22.6\% of the population) living in Latvia, while in 2050 , the total number of pensioners will be 311,000 ( $21.8 \%$ of the population). An increase in the number of pensioners can be forecast both in Pieriga and in the eastern part of Latgale.

The most significant increase in the number of pensioners in the period between 2011 and 2019 (Figure 2) was observed in Mārupe municipality, where the proportion reached $13-15 \%$ of the total population", as well as in Brocēni, Jelgava, Babīte, Ādaži and Carnikava municipalities, as well as in some municipalities in Latgale. The only municipality with a negative increase in the number of pensioners was Mērsrags municipality.

When assessing the change in the number of pensioners, the fact that there are care facilities for the elderly in several densely populated areas must be taken into account. For example, in Saldus, Skrunda and Vainode municipalities there are the care facilities Lutrinu Rietumos and Valtaiķi - the people living there make up a large proportion of the population of retirement age in those areas. 
Average pension payments in the country, which was calculated using data for the period from 2011 to 2018, shows a very close correlation with the indicators of gross domestic product per capita (the value of the correlation coefficient is 0.98 ). It is less closely correlated with net migration (0.81), life expectancy (in years) (0.88) and and the share of the total population who are economically active (employed people, and non-working people seeking employment) (0.94). Based on the obtained results, it can be concluded that average pension payments in municipalities are significantly influenced by trends in population movement, as there is a tendency for average pension payments to increase as the value of the migration balance increases. The highest level of pension payments in 2019 were observed in areas of Pieriga, where also the population is increasing every year, while lower pension payments are received by residents who live farther from Riga and Pieriga. According to statistical calculations, the difference between the average pension payment in municipalities in Vidzeme, Kurzeme, Zemgale and Latgale regions (in 2019) and the pension payments received in Pieriga municipalities is statistically significant, at $95 \%$ confidence level. Similar trends were also observed in relation to life expectancy and the proportion of the population who are economically active - in municipalities where this indicator is higher, so are the average pension payments.

\section{Conclusion}

According to the results obtained during the study, a significant future problem will be not so much the population decline, but its consequences - labour shortage or lower availability of labour, which is already creating an impact on the Latvian economy, and will cause an even greater impact in the future.

As the population ages, the number of workers retiring will increase significantly each year and will at some point exceed the number of people entering the labour market.

This will have a negative impact on the overall growth of society, considering that growth is driven by increased employment and higher productivity. The ageing of the population will also change the structure and extent of public expenditure and revenue. With the share of the older population increasing, the current and future workforce can expect an increase in income and indirect taxes, such as value-added $\operatorname{tax}$.

It can be predicted that around 2030, the ageing of the population will become one of the most serious problems in Pieriga, as well as in many other Latvian municipalities. Currently in $26 \%$ of all Latvia municipalities already more than $25 \%$ of the inhabitants are 65 or over and this number will continue to grow as the number of working-age people declines.

Average payment payments in municipalities are significantly influenced by trends in the movement of people, as there is a tendency that as the value of the migration balance increases, the average size of pensions also increases. 


\section{Kopsavilkums}

Rakstā tiek analizētas Latvijas sabiedrības novecošanās tendences, kas, visticamāk, kḷūs par vienu no vissvarīgākajām sociālajām pārmain̄ām 21. gs. Eiropas Savienībā un Latvijā. Darba rezultātu pamatā ir Latvijas Centrālās statistikas pārvaldes (CSP) un Latvijas Valsts sociālās apdrošināšanas aǵentūras (VSAA) dati. Iegūtie rezultāti liecina, ka ekonomiskās attīstības pieaugumu un nodarbinātības stabilizāciju Rīgā un Rīgas reǵionā 21. gs. otrajā desmitgadē nodrošināja nevis paaudžu maiņa vai migrācija, bet gan to iedz̄ivotāju iekḷaušana darba tirgū, kuri līdz tam nebija ekonomiski aktīvi. Viens no iegūtajam secinājumiem izsaka brīdinājumu, ka Pierīgā ap 2030. gadu iedzīvotāju novecošanās kḷūs par vienu no vissvarīgākajām problēmām.

\section{References}

Alho, J. and Spencer, B. (2006). Statistical demography and forecasting. Springer Science \& Business Media.

Apsīte-Beriņa, E., Burgmanis, G. and Krišjāne, Z. (2018). Return Migration Trends in Latvia: Reattracting the Main Human Resource for Sustainable Regional Development. Proceedings of the 12th International Scientific and Practical Conference. Volume I, 16.

Apsīte-Beriņa, E., Burgmanis, G̣. and Krišjāne, Z. (2019). Exploring Labour Migration from Latvia: Geographies of Origin. Folia Geographica XVII: Appreciating Geography. Local and Global Scale. 94101 .

Arango, J. (2017). Theories of international migration. In: Joly, D. (ed.) International migration in the new millennium. Routledge, 25-45.

Backus, D., Cooley, T. and Henriksen, E. (2014). Demography and low-frequency capital flows. Journal of International Economics, 92, 94-102.

Bloom, D.E. and Luca, D.L. (2016). The global demography of aging: facts, explanations, future. In: Piggott, J. and Woodland, A. (eds.) Handbook of the Economics of Population Aging, Volume 1. NorthHolland, 3-56.

Brekke, J.P. and Brochmann, G. (2015). Stuck in transit: secondary migration of asylum seekers in Europe, national differences, and the Dublin regulation. Journal of Refugee Studies, 28 (2), 145-162.

Burgmanis, G̦., Krišjāne, Z. and Šksilters, J. (2014). Acquisition of spatial knowledge in different urban areas: evidence from a survey analysis of adolescents. Cognitive Processing, 15 (3), 373-383.

Colby, S.L. and Ortman, J.M. (2014). The baby boom cohort in the United States: 2012 to 2060. US Census Bureau, 1-16.

Cuaresma, J. C., Lutz, W. and Sanderson, W. (2014). Is the demographic dividend an education dividend? Demography, 51 (1), 299-315.

Danchev, V. and Porter, M.A. (2018). Neither global nor local: Heterogeneous connectivity in spatial network structures of world migration. Social Networks, 53, 4-19.

De Vries, L. A., Guild, E. (2019). Seeking refuge in Europe: spaces of transit and the violence of migration management. Journal of Ethnic and Migration Studies, 45 (12), 2156-2166.

Envirotech (2013). GIS Latvija 10.2. Datu bāze. http://old.envirotech.lv/lv/aktualitates/gis-latvija10-2/ (09.02.2020)

European Statistical System handbook for quality and metadata reports (2020). Manual and guidelines. Eurostat. https://ec.europa.eu/eurostat/documents/3859598/10501168/KS-GQ-19-006-ENN.pdf/bf98fd32-f17c-31e2-8c7f-ad41eca91783 (30.03.2020).

Giacalone, D., Wendin, K., Kremer, S., Frøst, M. B., Bredie, W. L., Olsson, V. and Risvik, E. (2016). Health and quality of life in an aging population-Food and beyond. Food Quality and Preference, 47, 166-170.

Göler, D. and Krišjāne, Z. (2016). Elusive Migration Systems: Shifting from Transnationalism to Transregionalism. In: Domínguez-Mujica, J. (ed.) Global Change and Human Mobility. Springer: Singapore, 25-36. 
Göler, D., Krišjāne, Z. and Bērziņš, M. (2014). International migration in periods of transition and crisis. The example of Latvia. Baltic Region, 2 (20), 75-85.

Govindaraju, D.R. (2014). Opportunity for selection in human health. Advances in Genetics, 87, 170 .

Juselius, M. and Takáts, E. (2015). Can demography affect inflation and monetary policy? Bank for International Settlements Working Papers, 485, 1-50.

Krisjane, Z., Apsite-Berina, E., Berzins, M. and Grine, I. (2017). Regional topicalities in Latvia: Mobility and Immobility in the Countryside. Economic Science for Rural Development Conference Proceedings, 45, 127-133.

LR CSP (2020). CSP publicē Latvijas karti ar senioru visblīvāk apdzīvotajām teritorijām. https://www.csb.gov.lv/lv/statistika/statistikas-temas/iedzivotaji/teritoriala-eksperimentala/meklettema/2831-senioru-visblivak-apdzivotas (30.03.2020).

Maestas, N., Mullen, K. J. and Powell, D. (2016). The effect of population aging on economic growth, the labor force and productivity. National Bureau of Economic Research Working Paper Series.

McAuliffe, M. and Ruhs, M. (2017). World Migration Report 2018. Geneva: International Organization for Migration.

McCollum, D., Apsite-Berina, E., Berzins, M. and Krisjane, Z. (2017). Overcoming the crisis: the changing profile and trajectories of Latvian migrants. Journal of Ethnic and Migration Studies, 43 (9), 1508-1525.

Nica, E. (2015). Labor Market Determinants of Migration Flows in Europe. Sustainability, 7 (1), 634-647.

O’Reilly, J., Eichhorst, W., Gábos, A., Hadjivassiliou, K., Lain, D., Leschke, J. and Russell, H. (2015). Five characteristics of youth unemployment in Europe: Flexibility, education, migration, family legacies, and EU policy. Sage Open, 5 (1).

OECD (2008). Handbook on Constructing Composite Indicators. Methodology and User Guide. Organisation for Economic Co-operation and Development publications. http://www.oecd.org/sdd/42495745.pdf (31.03.2020)

Paiders, J. (2019). Projected changes in the number of inhabitants of Latvia in the event of the stabilization of emigration. Folia Geographica XVII. Appreciating Geography: Local and Global Scale, 77-84.

Population projections 2015 at national level (2015). Population on 1st January by age, sex and type of projection http://appsso.eurostat.ec.europa.eu/nui/show.do?dataset=proj_15npms\&lang=en (30.03.2020)

Rechel, B., Mladovsky, P., Ingleby, D., Mackenbach, J. P. and McKee, M. (2013). Migration and health in an increasingly diverse Europe. The Lancet, 381 (9873), 1235-1245.

Sanderson, W.C., Scherbov, S. and Gerland, P. (2017). Probabilistic population aging. PloS One, 12 (6)

Stillwell, J., Bell, M., Ueffing, P., Daras, K., Charles-Edwards, E., Kupiszewski, M. and Kupiszewska, D. (2016). Internal migration around the world: comparing distance travelled and its frictional effect. Environment and Planning A, 48 (8), 1657-1675.

Wilson, C., Sobotka, T., Williamson, L. and Boyle, P. (2013). Migration and intergenerational replacement in Europe. Population and Development Review, 39 (1), 131-157.

Zavras, D., Tsiantou, V., Pavi, E., Mylona, K. and Kyriopoulos, J. (2013). Impact of economic crisis and other demographic and socio-economic factors on self-rated health in Greece. The European Journal of Public Health, 23 (2), 206-210. 